\title{
Kön och sexualitet i Simone de Beauvoirs Le Deuxième Sexe
}

\author{
Av Christina Angelfors, Franska, Växjö universitet
}

\section{Inledning}

Det ideologiska klimat som är rådande när Simone de Beauvoir påbörjar arbetet med Le Deuxième Sexe är starkt präglat av en naturalistisk tanketradition. Utmärkande för det naturalistiska synsättet på förhållandet mellan människa och samhälle är att man försöker hitta naturliga förklaringar, oftast hämtade från biologin, på sådant som egentligen är sociala fenomen, till exempel kvinnors underordnade ställning (Delphy 1998:21). Det är denna förklaringsmodell som Simone de Beauvoir i sin analys föresätter sig att bryta mot. Dock är detta ett tungt arv som Beauvoir inte helt lyckas befria sig från, vilket förklarar en del motsägelser och inkonsekvenser i hennes text.

Brottet med den naturalistiska traditionen kan sammanfattas i tre punkter (Armengaud, 2002:25). 1. Filosofiskt: Beauvoirs analys grundar sig på existentialismens tes att "varat föregår väsendet", det vill säga människan saknar väsen eller essens. Hon har ingen inneboende natur; människan är inget annat än det hon gör. 2. Epistemologiskt: orsaker och förklaringar söks i samhället, civilisationen och kulturen. 3. Politiskt: den ständigt återkommande tanken att det inte finns något förutbestämt öde inger hopp om att tingens ordning kan förändras.

Går man in på ett närmare studium av Beauvoirs text märker man emellertid att brytningen med den naturalistiska förklaringsmodellen långt ifrån är fullständig. Detta är trots allt på inget sätt anmärkningsvärt: ett paradigmskifte kan knappast äga rum i ett enda slag, ännu mindre åstadkommas av en enda person (Delphy 2002:193). Min avsikt med att lyfta fram motsägelserna i Beauvoirs analys är därför inte att kritisera henne. Tvärtom menar jag att just dessa motsägelser är intressanta. Jag tror nämligen att vi fortfarande, såväl människor i allmänhet som forskarsamhället, lever kvar i en föreställningsvärld präglad av det naturalistiska arvet. Det som vållade problem för Beauvoir 1949 är enligt min mening i långa stycken problematiskt ännu idag. Ett av dessa problemområden är förhållandet mellan kön och sexualitet. Där kan en närläsning av Beauvoirs text dels visa på var svårigheterna ligger, dels bekräfta det faktum att Le Deuxième Sexe innehåller fröet till såväl nutida genus- som queerteori.

\section{Den existentialistiska diskursen: sexualiteten som val}

I sann fenomenologisk anda inleder Simone de Beauvoir sin essä med frågan "Vad är en kvinna?" - "qu’est-ce qu’une femme?" (Beauvoir 1949, 2:11; sv. öv. 2002:23). Ett fenomenologiskt förhållningssätt innebär, som Eva Gothlin påpekar i förordet till den nya svenska översättningen av boken, att man förutsättningslöst försöker beskriva ett visst fenomen för att därefter söka bestämma dess mening. När Beauvoir vill undersöka kvinnan som fenomen avser hon alltså att ta reda på vad som gör kvinnan till kvinna (Gothlin 2002:12-13). Svaret på frågan får vi på sätt och vis i den berömda tesen med vilken kapitlet om barndomen inleds: "On ne naît pas femme; on le devient" (1949, 1:285) - "Man föds inte till kvinna, man blir det" (2002:325). Att kvinnan som biologisk varelse i flera avseenden skiljer sig från mannen är inget som Beauvoir förnekar, varken här eller i senare uttalanden (Beauvoir 1972:614). Nej, den springande punkten är istället konstaterandet att varje mänsklig honvarelse nödvändigtvis inte är en kvinna. För att bli betraktad som sådan 
måste hon "vara del av den mystiska och hotade realitet som är kvinnligheten" (2002:23). I analogi med den existentialistiska tesen om människans avsaknad av essens avvisar Beauvoir tanken på en inneboende kvinnlig natur. Det som kallas kvinnlighet är inget av naturen givet utan ett av samhället och kulturen konstruerat fenomen. I motsats till traditionellt tänkande, som ser ett naturligt samband mellan kvinnligt kön och kvinnlighet, liksom mellan manligt kön och manlighet, skiljer alltså Beauvoir dessa båda kategorier åt. Således kan en kvinna enligt Beauvoirs mening antingen vara kvinnlig eller manlig beroende på vilka val hon gör i livet.

Beauvoirs syn på kvinnlighet och manlighet som kulturella konstruktioner som vi kan välja mellan har vunnit gehör i vida kretsar, särskilt inom feminismen och genusforskningen. Huruvida den breda allmänheten tagit till sig dessa tankar får förbli osagt. Vad som däremot inte väckt någon större uppmärksamhet är den tes som Beauvoir driver i kapitlet "Den lesbiska kvinnan", nämligen att även sexualiteten är något vi kan välja. I Sverige kan detta möjligen bero på att det här kapitlet saknades i den första och mycket ofullständiga översättningen av Le Deuxième Sexe. I den anglosaxiska världen är det uppenbart att Judith Butler och queerteorin har hämtat mycket av sin inspiration från Beauvoir. Det är efter en diskussion av möjliga förklaringar till homosexualiteten som Beauvoir gör följande sammanfattning:

I själva verket finns det aldrig en avgörande faktor, det handlar alltid om ett val som träffats i ett komplext sammanhang och som vilar på ett fritt beslut. Det finns inget sexuellt öde som styr individens liv, sexualiteten är tvärtom ett uttryck för individens hela inställning till existensen.

(2002:480)

Med "destin sexuel" eller "sexuellt öde" menar alltså Beauvoir att individens sexuella läggning inte är ödesbestämd - människan väljer själv sin sexualitet. Om man extrapolerar Beauvoirs tes om hur man blir kvinna, skulle man följaktligen kunna säga: man föds inte till homosexuell; man blir det. I logikens namn föds man då inte heller till heterosexuell, men där kan man konstatera en blind fläck i Beauvoirs analys. Heterosexualiteten framställs aldrig som en konkret valmöjlighet, endast som något man kan välja bort till förmån för något annat.

I vilka situationer kan då Beauvoir konstatera att kvinnor väljer homosexualitet framför heterosexualitet? För att analysera och förklara dessa val använder Beauvoir de existentialistiska motsatsparen subjekt - objekt, aktiv - passiv. Kvinnor vill, precis som män, vara aktiva subjekt, menar Beauvoir, men mannen och det omgivande samhället kräver av kvinnan att hon gör sig till objekt, att hon intar en passiv hållning. Denna grundläggande motsättning i kvinnors liv löser vissa genom att välja homosexuella relationer. Således kan en kvinna välja att bli lesbisk "därför att hon vägrar att bli dominerad av mannen" (2002:481); två kvinnor "kan älska varandra i jämlikhet" (2002:481); "i en exakt ömsesidighet är var och en samtidigt subjekt och objekt, härskarinna och slav, dualiteten innebär samförstånd" (2002:478).

Homosexualiteten som ett sätt för kvinnan att "fly från sin situation" (2002:468) anser Beauvoir vara utmärkande för kvinnor med en utpräglat aktiv personlighet: kvinnor som är engagerade i egna projekt eller som kräver frihet i största allmänhet, intellektuella och handlingskraftiga kvinnor (2002:472). Att som kvinna under rådande omständigheter vara ett aktivt subjekt i en heterosexuell relation framstår i Beauvoirs analys som en omöjlighet. Om däremot jämlikheten mellan könen vore konkret förverkligad skulle dessa kvinnor i många fall kunna tänkas välja annorlunda, menar Beauvoir (ibid.).

Den heterosexuella normen är anmärkningsvärt stark i Beauvoirs text. Det homosexuella valet ses i första hand som en protest mot en samhällsordning som hindrar kvinnor från att förverkliga sig själva. Något egentligt ifrågasättande av denna heterosexuella norm, vilket är själva grunden för queerteorin, kan man alltså inte finna hos Beauvoir.

Simone de Beauvoirs egen definition på vad en homosexuell kvinna är kan enligt min mening ytterligare belysa hennes inställning i denna fråga. Unga flickor, säger Beauvoir, 
kan ha intensiva homosexuella relationer för att senare i livet bli kärleksfulla hustrur. "Det som hos den inverterade kräver en förklaring är alltså inte den positiva aspekten av hennes val utan den negativa. Hon utmärks inte av sin böjelse för kvinnor, utan av exklusiviteten i denna böjelse" (2002:469). Det är med andra ord positivt att ha relationer med kvinnor, men det är negativt att enbart begränsa sig till kvinnor. Här ser man alltså konturerna av bisexualitet avteckna sig som ett slags idealt tillstånd, dock utan någon analys av bisexualiteten som fenomen. Inte heller figurerar själva termen i Beauvoirs text.

Efter publiceringen av Beauvoirs brev till Sartre vet vi att bisexuella relationer utgjorde Simone de Beauvoirs egen verklighet. Det kan därför tyckas märkligt att denna valmöjlighet inte närmare analyseras eller ens benämns. För Beauvoirs egen person har Mariam Fraser i boken Identity without Selfhood. Simone de Beauvoir and Bisexuality (1999) kunnat visa hur en rad betydande Beauvoirforskare antingen betecknar henne som heterosexuell eller som lesbisk, aldrig som bisexuell. Anledningen till detta menar Fraser vara att bisexualitet inte är något identitetsgrundande, något tillhörande ett själv, såsom fallet är med hetero- och homosexualitet (Fraser 1999:98). Jag skulle vilja påstå att inte heller Beauvoir själv såg bisexualitet som en identitetsgrundande kategori utan snarare som en sida av heterosexualiteten. Detta skulle kunna förklara varför termen inte förekommer i hennes text och varför bisexualitet inte framställs som en valmöjlighet. För Beauvoir finns det egentligen bara två grupper av kvinnor: de heterosexuella, av vilka somliga ibland väljer att ha relationer med andra kvinnor och de lesbiska. Det Beauvoir i ett av sina brev betecknar som att vara "lesbienne professionnelle" (Beauvoir 1990 2:392), det vill säga de som har relationer enbart med andra kvinnor. Det är givet att Beauvoir ser sig själv som hemmahörande i den första kategorin, den som tillhör normen, vilket innebär att alla etiketter blir obehövliga. Kanske har vi här förklaringen till Beauvoirs mycket omdiskuterade tystnad kring sin egen sexualitet. För henne fanns det helt enkelt ingenting att förklara.

\section{Det naturalistiska arvet: kroppen som öde}

Kapitlet "Den lesbiska kvinnan" inleds med att Beauvoir avfärdar den mycket seglivade myten om att den lesbiska kvinnans manlighet "skulle vara en anomali som motsvarar en hormonell obalans. Inget kan vara mer felaktigt, säger Beauvoir, än denna sammanblandning av den inverterade och den manhaftiga kvinnan. Det finns många homosexuella bland haremskvinnor och kurtisaner, bland de mest uttalat 'feminina' kvinnor, och omvänt är många maskulina kvinnor heterosexuella" (2002:466). Det Beauvoir här åstadkommer är inte bara en dekonstruktion av det så kallade naturliga sambandet mellan kön och genus (en kvinna kan vara manlig), utan också det mellan genus och därtill hörande sexuell orientering: manliga kvinnor kan vara heterosexuella och kvinnliga kvinnor homosexuella (Angelfors, 2002:286).

Parallellt med denna konstruktivistiska syn på relationen kön/genus/sexualitet finner man emellertid en starkt naturalistisk ådra. Som Sylvie Chaperon visat i sin artikel "La deuxième Simone de Beauvoir" kan man beteckna det epistemologiska brottet i Le Deuxième Sexe som ofullbordat (Chaperon 1997:138). Ett av de ställen där två motsatta ideologier, den naturalistiska och den konstruktivistiska, bryts allra tydligast mot varandra är i analysen av den manliga lesbiska kvinnan. Det är hon som i Beauvoirs ögon inkarnerar "la lesbienne". Det är uppenbart att hon både fascinerar och provocerar Beauvoir. En liknande iakttagelse gjordes av fotografen Elisabeth Ohlson i samband med visningen av utställningen Könskrigare (Växjö universitet, 7 december 2001). Det är de "butchiga" kvinnorna som utmanar och provocerar mest; det är de som allra mest stör vår uppfattning om hur en kvinna ska se ut och vara.

Vi har tidigare sett hur Beauvoir i mycket positiv ton talar om de kvinnor som ikläder sig en kulturell manlighet, det vill säga de aktiva kvinnorna, de som uppträder som självständiga individer, som subjekt. Analysen av den kulturella manligheten genomsyras av en konstruktivistisk syn. Anledningen till att dessa kvinnor av samhället uppfattas som 
manliga är, säger Beauvoir, att det är mannen som i dagens samhälle representerar det positiva och det neutrala, den mänskliga varelsen, medan kvinnan enbart är det negativa, honan. "Varje gång hon uppträder som en mänsklig varelse förklarar man således att hon identifierar sig med mannen" (2002:469). Att ta på sig rollen som aktivt subjekt med risk för att därmed betecknas som manlig ser alltså Beauvoir som ett positivt val.

När Beauvoir däremot kommer in på sexualitetens område dyker den naturalistiska synen upp. Marie-Hélène Bourcier konstaterar i sin artikel "La 'lesbeauvoir' entre féminité, féminisme et masculinité ou comment contenir les lesbiennes 'butchs'", att om Beauvoir dekonstruerar sambandet mellan kön och genus så framstår det mellan kön och sexualitet som desto naturligare (Bourcier 2002:279). Beauvoirs analys bygger här på antagandet att det finns en strikt koppling mellan det biologiska könet och det sexuella beteendet: män är sexuellt aktiva, kvinnor sexuellt passiva. Kategorierna subjekt - objekt, aktiv - passiv blir nu laddade med ett naturalistiskt, biologistiskt innehåll. Särskilt tydligt blir detta i beskrivningen av den manliga lesbiska kvinnans sexualitet. Det "anatomiska öde" som Beauvoir i början av kapitlet avvisar - "Inget 'anatomiskt öde' avgör deras sexualitet" (2002:466) - kommer i själva verket att inta en central plats i definitionen av "la lesbienne virile".

Den manliga lesbiska kvinnan tillskrivs av Beauvoir en aktiv roll i den sexuella akten, men eftersom hon alltid kommer att sakna manligt organ förblir hon en kastrat (2002:474); hennes anatomi gör henne lika klumpig och maktlös som en eunuck: hennes begär att äga, att ta misslyckas eftersom hon saknar ett organ i vilket begäret kan inkarneras (2002:436). Den lesbiska kvinnan är ofullbordad som kvinna, impotent som man, och det obehag denna situation framkallar tar sig ibland uttryck i psykoser (2002:474). Homosexualiteten framstår som något ofullständigt, menar Beauvoir (2002:468). Det är ganska uppenbart att för henne är det den heterosexuella kvinnan som representerar den normala och den kompletta kvinnan (2002:404, 474). Ordet normal är för övrigt högfrekvent i det här kapitlet. Det tycks alltså vara så att för Beauvoir vid denna tid är anatomin trots allt ödet, precis som Freud sade: "L’anatomie, c’est le destin" (citerat av Beauvoir 1949, 1:62; 2002:80). I denna kontext framstår alltså det homosexuella valet som ett negativt val, som något som begränsar och stympar individen.

\section{Efter Le Deuxième Sexe}

Om man vill studera Beauvoirs senare utveckling av synen på kön och sexualitet så kan man med fördel ta del av den serie intervjuer som den tyska journalisten Alice Schwarzer gjorde med Beauvoir mellan åren 1972 och 1982. I intervjun från 1976 finner man att Beauvoir i stort sett håller fast vid sin analys i Le Deuxième Sexe. Såväl hetero- som homosexualitet är tvångströjor: "En soi, l’homosexualité est aussi limitante que l’hétérosexualité : l’idéal devrait être de pouvoir aussi bien aimer une femme qu'un homme" (Schwarzer 1984:82; min öv. I sig är homosexualitet lika begränsande som heterosexualitet: idealet borde vara att kunna älska såväl en kvinna som en man). Bisexualitet, ett ord som dock fortfarande inte används, framstår alltså som den absoluta friheten.

Går man till den sista intervjun från 1982, i vilken Schwarzer tar upp frågan om homosexualitet som en politisk strategi, kan man konstatera att Beauvoirs syn radikalt har förändrats. På frågan om homosexualitet tycks henne acceptabelt, åtminstone i teorin, svarar Beauvoir: "Totalement. Totalement acceptable. Les femmes ne devraient plus être conditionnées uniquement pour le désir de l’homme" (Schwarzer 1984:119; min öv. Fullständigt. Fullständigt acceptabelt. Kvinnor borde inte längre vara betingade enbart för mannens åtrå). Den idealistiskt färgade synen på sexualiteten som ett fritt val har alltså ersatts av en materialistisk analys där sexualiteten ses som en av grundvalarna i en maktordning, och kanske det främsta sättet att reproducera denna ordning.

Detta var alltså Beauvoirs analytiska position vid sin död. Var hon skulle ha stått idag är svårt att sia om. Skulle hon anslutit sig till dagens biteoretiker eller skulle hon hållit fast vid 
sin radikalfeministiska position? Förmodligen skulle hon ställt sig på den sida som hon uppfattat som mest radikal. Och den mest radikala ståndpunkten att inta i dagens samhälle är kanske den som kommer till uttryck i ett av bidragen till lambda nordicas temanummer om bisexualitet, "Både och/ och /varken eller", nämligen den att verka för en birörelse som är uttalat feministisk (Ekström 2001:51).

\section{(C) Christina Angelfors}

\section{Referenser}

Angelfors, Christina (2002) "Le lesbianisme et l'homosexualité dans Le Deuxième Sexe", i Christine Delphy, Sylvie Chaperon (éd.), Cinquantenaire du Deuxième Sexe. Paris: Éd. Syllepse.

Armengaud, Françoise (2002) "Le matérialisme beauvoirien et la critique du naturalisme : une rupture épistémologique inachevée?", i Christine Delphy, Sylvie Chaperon (éd.), Cinquantenaire du Deuxième Sexe. Paris: Éd. Syllepse.

Beauvoir, Simone de (1949) Le Deuxième Sexe. 2 vols. Paris: Gallimard.

Id. (1972) Tout compte fait. Paris: Gallimard.

Id. (1990) Lettres à Sartre. 2 vols. Paris: Gallimard.

Id. (2002) Det andra könet. Översättning Adam Inczèdy-Gombos \& Åsa Moberg. I samarbete med Eva Gothlin. Stockholm: Norstedts.

Bourcier, Marie-Hélène (2002) "La 'lesbeauvoir' entre féminité, féminisme et masculinité ou comment contenir les lesbiennes 'butchs'", i Christine Delphy, Sylvie Chaperon (éd.), Cinquantenaire du Deuxième Sexe. Paris: Éd. Syllepse.

Chaperon, Sylvie (1997) "La deuxième Simone de Beauvoir", i Les Temps Modernes, avril- mai, 593:112-143.

Delphy, Christine (1998) L’Ennemi principal. 1/ Économie politique du patriarcat. Paris: Éd. Syllepse.

Id. (2002) "Les débats féministes contemporains. Introduction", i Christine Delphy, Sylvie Chaperon (éd.), Cinquantenaire du Deuxième Sexe. Paris: Éd. Syllepse.

Ekström, Karin (2001) "Bisexuell och feminist. En paradox eller den ultimata subversionen?", i lambda nordica, vol. 5, 1-2:44-53.

Fraser, Mariam (1999) Identity without Selfhood. Simone de Beauvoir and Bisexuality. UK: Cambridge University Press.

Gothlin, Eva (2002) "Förord" till Det andra könet. Stockholm: Norstedts.

Schwarzer, Alice (1984) Simone de Beauvoir aujourd'hui. Six entretiens. Paris: Mercure de France. 